CORRECTION

\title{
Correction to: Neuroimaging and modulation in obesity and diabetes research: 10th anniversary meeting
}

Maren Laughlin, Bradley Cooke (D), Kerri Boutelle, Cary R. Savage, Alexxai Kravitz, Dana Small (D), Zoe Arvanitakis, Alex Martin and Luke E. Stoeckel iD

(c) This is a U.S. government work and not under copyright protection in the U.S.; foreign copyright protection may apply 2022

International Journal of Obesity (2022) 46:889; https://doi.org/10.1038/s41366-022-01074-7

Correction to: Int J Obes https://doi.org/10.1038/s41366-021-01025-8

The original version of this article unfortunately contained a mistake. The following statement was missing in the article: Disclaimer Statement: The content is solely the responsibility of the authors and does not represent the official views of the NIH or federal government.

\section{Acknowledgements}

The workshop entitled "Neuroimaging and Modulation in Obesity and Diabetes Research 10th Anniversary Meeting", that served as an important foundation for this review article, was supported by the NIDDK of the NIH. We would like to thank the authors for their service on the workshop planning committee. $B C, M L$, and LES were lead authors. All other listed authors contributed equally to the workshop report. All listed speakers contributed to authorship for their section of the report.
The authors apologize for the mistake. The original article has been corrected.

\footnotetext{
(c) (i) Open Access This article is licensed under a Creative Commons cc) Attribution 4.0 International License, which permits use, sharing, adaptation, distribution and reproduction in any medium or format, as long as you give appropriate credit to the original author(s) and the source, provide a link to the Creative Commons license, and indicate if changes were made. The images or other third party material in this article are included in the article's Creative Commons license, unless indicated otherwise in a credit line to the material. If material is not included in the article's Creative Commons license and your intended use is not permitted by statutory regulation or exceeds the permitted use, you will need to obtain permission directly from the copyright holder. To view a copy of this license, visit http://creativecommons. org/licenses/by/4.0/.

(c) This is a U.S. government work and not under copyright protection in the U.S.; foreign copyright protection may apply 2022
} 